\title{
Welke factoren bepalen de implementatie van een lokale integrale aanpak van overgewicht bij kinderen?
}

\author{
Rianne M. J. J. van der Kleij · Matty R. Crone · Ria Reis · Theo G. W. M. Paulussen
}

(C) Bohn Stafleu van Loghum is een imprint van Springer Media B.V., onderdeel van Springer Nature 2017

\begin{abstract}
Samenvatting In Nederland zijn al vele initiatieven ontwikkeld om overgewicht onder kinderen terug te dringen. De implementatie van dergelijke interventies gaat echter niet vanzelf; zeker niet in het geval van een integrale aanpak die om een bijdrage vraagt van meerdere sectoren en professionals. Om inzicht te krijgen in factoren die bepalend zijn voor het succes en falen van de implementatie van een integrale aanpak van overgewicht, is het implementatieproces van de aanpak gedurende anderhalf jaar onderzocht in vijf Nederlandse gemeenten. Factoren zijn onderzocht aan de hand van een aangepaste versie van het MeetInstrument voor Determinanten van Innovaties (MIDI). Van de 256 benaderde professionals heeft $45 \%$ de vragenlijst ingevuld. Het hiërarchisch multivariate lineaire regressiemodel dat het best bij de data paste verklaarde $65 \%$ van de variantie in de implementatiegraad. De beste verklaring boden de factoren eigen-effectiviteitsverwachting, gelegenheid om ervaring op te doen met de aanpak, een niet te ambitieus samengesteld pakket van invoeringsactiviteiten en betrokkenheid bij de implementatie in een van de onderzochte wijken ('Wijk B' genoemd). Op basis van de resultaten worden aanbevelingen gedaan voor toekomstige
\end{abstract}

R. M. J. J. van der Kleij $(\bowtie) \cdot$ M. R. Crone · R. Reis

Department of Public Health and Primary Care, Leiden

University Medical Center, Leiden, Nederland

M.J.J.van_der_Kleij@lumc.nl

R. Reis

Amsterdam Institute for Social Science Research, University of Amsterdam, Amsterdam, Nederland

The Children's Institute, School of Child and Adolescent Health, University of Cape Town, Kaapstad, Zuid-Afrika

T. G. W. M. Paulussen

TNO Innovation for Life, Expertise Center Child Health,

Leiden, Nederland verbetering van de invoeringspraktijk en het onderzoek naar de implementatie van dergelijke integrale preventieprogramma's.

Trefwoorden overgewicht · jongeren - implementatie . integrale aanpak · intersectorale samenwerking

\section{Inleiding}

De hoge prevalentie van overgewicht bij kinderen wordt gezien als een van de grootste gezondheidsuitdagingen van de 21ste eeuw [1]. Overgewicht tijdens de kindertijd kan resulteren in onmiddellijke en toekomstige schadelijke gezondheidsuitkomsten, zoals diabetes mellitus type 2, hart- en vaatziekten, kanker en psychosociale problemen [2]. De etiologie van overgewicht bij kinderen is multifactorieel [3]. Dit pleit voor een integrale aanpak, die zowel aangrijpt op het niveau van het kind, het gezin, als de omgeving. Een voorbeeld van een dergelijke integrale

\section{Kernpunten}

- De succes- en faalfactoren bij de implementatie van een integrale aanpak van overgewicht zijn onderzocht door middel van een vragenlijstonderzoek onder professionals met taken op dit terrein.

- Uit dit onderzoek blijkt dat professionals die langer betrokken zijn bij de implementatie van integrale preventie dit succesvoller doen.

- Het verhogen van de eigen effectiviteit van professionals, bijvoorbeeld door coaching of deelname aan stakeholder-meetings, bevordert vermoedelijk de implementatie van integrale preventieprogramma's. 
aanpak is het Franse 'Ensemble Prévenons l'Obesité des Enfants' (EPODE) [4]. In EPODE staat de gedachte centraal dat een gezonde leefstijl van kinderen wordt gefaciliteerd door een non-obesogene omgeving. EPODE steunt daarbij op vier pijlers, namelijk 1) het creëren van politiek draagvlak, 2) het gebruik van sociale marketing, 3) de inzet van publiek-private samenwerking en 4) een wetenschappelijke evaluatie. De EPODE-aanpak is minimaal geprotocolleerd. Een gemeente krijgt een set algemene richtlijnen, materialen en tips aangeboden, waaruit men grotendeels zelf een concrete uitwerking moet destilleren. EPODE heeft die strategie bewust gekozen, zodat gemeenten een aanpak ontwerpen die aansluit bij de eigen specifieke context. In twee kleine Franse dorpen bleek de EPODE-aanpak succesvol bij het verminderen van overgewicht bij kinderen [5]. In navolging van dit succes werd in Nederland de op EPODE gebaseerde aanpak Jongeren Op Gezond Gewicht (JOGG) ontwikkeld. JOGG volgt de vier pijlers van EPODE en voegt daar nog een vijfde aan toe: de verbinding tussen preventieve en curatieve zorg. Ondanks de bemoedigende resultaten van EPODE in de twee Franse dorpen, is in de meeste gevallen waarbij de aanpak is gerepliceerd de effectiviteit bescheiden gebleken [6]. Vaak wordt de oorzaak daarvan toegeschreven aan een onvolkomen implementatie; de implementatie van een integrale aanpak is immers complex en daardoor foutgevoelig [7]. Daarom is vanuit CIAO nadrukkelijk ingezet op onderzoek dat licht werpt op het proces van de implementatie van de integrale aanpak in vijf Nederlandse gemeenten.

Het implementatieonderzoek kende twee subvragen:

a) In hoeverre voeren betrokken professionals de preventieactiviteiten uit die van hen worden verwacht in het kader van de lokale integrale aanpak van overgewicht?

b) Welke factoren verklaren het best de mogelijke verschillen in graad van implementatie?

Het antwoord op de eerste vraag wordt gevonden in de discrepantie tussen het gewenste niveau en het actuele niveau van implementatie, zoals gerealiseerd in de betreffende gemeenten. Aangezien de 'ideale' integrale aanpak niet universeel is geprotocolleerd, kan voor het beantwoorden van de eerste onderzoeksvraag niet worden teruggegrepen op een extern evaluatiecriterium. Immers, het plan van aanpak zal en mag per locatie variëren. Om die reden is 'implementatie zoals bedoeld' ontleend aan het interne criterium: de set van preventieactiviteiten die elke gemeente/wijk zelf voornemens was te implementeren. Per gemeente is nagegaan in hoeverre de door hen zelf geplande/voorgenomen preventieactiviteiten daadwerkelijk in praktijk zijn gebracht. De vervolgvraag, die naar verklaringsfactoren, is het meest praktisch relevant omdat daarin de aangrijpingspunten gevonden worden voor mogelijke toekomstige verbetering van die implementatie. Het MeetInstrument voor Determinanten van Innovaties (MIDI) bood een bruikbaar vertrekpunt voor het modelleren van potentieel relevante verklaringsfactoren $[8,9]$. Dit instrument bevat 29 theoretisch en empirisch getoetste potentieel relevante factoren van implementatie van innovatieve interventies in de publieke gezondheid. Met behulp van de MIDI wordt nagegaan welke factoren op het niveau van de innovatie, beoogde gebruiker, organisatie, sociaal-politieke context en de tot dan gehanteerde invoeringsstrategie de implementatie-uitkomsten(en) bepalen.

\section{Methode}

In vijf Nederlandse gemeenten die een integrale aanpak overgewicht voor jeugdigen hebben geïmplementeerd is tussen februari 2013 en juni 2014 tweemaal onderzoek gedaan naar het implementatieproces. Daarbij zijn gemeten:

1. de compleetheid van de implementatie;

2. de factoren van invloed op de implementatie.

\section{Uitkomstvariabele 'compleetheid van implementatie'}

In de literatuur wordt een diversiteit aan definities gekoppeld aan het begrip 'implementatie zoals bedoeld', onder andere fidelity, compleetheid van gebruik (completeness), niveau van gebruik (level of use) en ontvangen dosis door de doelgroep (dosage received). Over hoe deze begrippen zich tot elkaar verhouden en hoe ze het best gemeten kunnen worden, bestaat vooralsnog geen consensus $[10,11,12]$. In aansluiting op het theoretische kader van Caroll et al. [13] is er in dit onderzoek voor gekozen het construct 'compleetheid van implementatie' te gebruiken als indicator voor de mate van implementatie van de lokale integrale aanpak van overgewicht. Compleetheid wordt daarbij gedefinieerd als 'de proportie van het totaalaantal voorgeschreven activiteiten dat daadwerkelijk in praktijk is gebracht'.

De criteriumvariabele 'compleetheid' is per gemeente bepaald aan de hand van het door de lokale partners zelf opgestelde implementatieplan. Uit de verschillende plannen konden per uitvoeringsorganisatie gemiddeld 19,7 ( $\mathrm{sd}=13,7$ ) activiteiten worden gedestilleerd. Per uitvoeringsorganisatie is vervolgens een implementatie-index samengesteld, waarbij respondenten voor elke activiteit konden aangeven of ze deze 'ja' (1) of 'nee' (0) hadden uitgevoerd. Zo werd in voorkomende gevallen bijvoorbeeld aan leerkrachten gevraagd 'Hebt $\mathrm{u}$ de kinderen fruit als een snack gegeven?' en 'Hebt u 's middags een buitenspelactiviteit georganiseerd?'. De maat voor compleetheid volgt dan uit het delen van het aantal uitgevoerde activiteiten door het totaalaantal voor hen bedoelde/ voorgeschreven activiteiten, vermenigvuldigd met honderd. 
Tabel 1 Achtergrondkenmerken en typering van de aanpak per gemeente

\begin{tabular}{|c|c|c|c|c|c|}
\hline Gemeente & $A$ & $B$ & C & D & $E$ \\
\hline Grootte (ha) & 428 & 103 & $2.320 / 184$ & 6.958 & 4.250 \\
\hline \# Inwoners & 27.095 & 13.100 & 7.345 & 41.005 & 18.200 \\
\hline $\begin{array}{l}\% \text { Gezinnen met } \\
\text { laag inkomen } 2012\end{array}$ & $61 \%$ & $56 \%$ & $59 \%$ & $35 \%$ & $34 \%$ \\
\hline $\begin{array}{l}\% \text { Niet-westerse } \\
\text { achtergrond }\end{array}$ & $54 \%$ & $25 \%$ & $17 \%$ & $4 \%$ & $6 \%$ \\
\hline Soort aanpak & JOGG & JOGG & JOGG & Op EPODE gebaseerd & Op EPODE gebaseerd \\
\hline $\begin{array}{l}\text { Implementatie- } \\
\text { niveau }\end{array}$ & Wijk & Wijk & Wijk & Gemeente & Gemeente \\
\hline Doelgroep & 0-12 jaar & 0-19 jaar & 0-12 jaar & 0-18 jaar & 0-18 jaar \\
\hline Typering strategie & top-down & top-down/bottom-up & top-down/bottom-up & bottom-up & bottom-up \\
\hline Focus aanpak & voeding & voeding/bewegen & bewegen & voeding/bewegen & voeding/bewegen \\
\hline \# Private partners & $>5$ & $<5$ & $>5$ & $<5$ & $<5$ \\
\hline \multicolumn{6}{|c|}{ Activiteiten per sector } \\
\hline Onderwijs & $\begin{array}{l}\text { Fruit- en watercam- } \\
\text { pagne: fruit en water- } \\
\text { momenten, informeren } \\
\text { ouders over voeding, } \\
\text { gadgets }\end{array}$ & $\begin{array}{l}\text { Project smakelijke moes- } \\
\text { tuinen Peuterspeelzaal/ } \\
\text { kinderdagverblijf }\end{array}$ & $\begin{array}{l}\text { Integraal, multidisci- } \\
\text { plinair schoolgezond- } \\
\text { heidsprogramma (Lekker } \\
\text { Fit!) }\end{array}$ & $\begin{array}{l}\text { Integraal, multidiscipli- } \\
\text { nair schoolgezondheids- } \\
\text { programma } \\
\text { Voorschools voedings- } \\
\text { en beweegbeleid }\end{array}$ & $\begin{array}{l}\text { Integraal, multidiscipli- } \\
\text { nair schoolgezondheids- } \\
\text { programma }\end{array}$ \\
\hline Gezondheidszorg & $\begin{array}{l}\text { Fruit- en watercam- } \\
\text { pagne: JGZ-consulten } \\
\text { versterken onder andere } \\
\text { door advies/gadgets over } \\
\text { fruit-/watergebruik }\end{array}$ & $\begin{array}{l}\text { Programma gezonde } \\
\text { voeding/weerbaarheids- } \\
\text { programma }\end{array}$ & Peuter/kleutergym & Peuter/kleutergym & - \\
\hline Welzijn en Sport & $\begin{array}{l}\text { Fruit- en watercam- } \\
\text { pagne } \\
\text { Integreren gezond be- } \\
\text { wegen en voeding in } \\
\text { activiteiten, verspreiden } \\
\text { gadgets }\end{array}$ & $\begin{array}{l}\text { Gezonde sportkantine } \\
\text { Combinatie functionaris- } \\
\text { sen } \\
\text { Sportactiviteiten }\end{array}$ & $\begin{array}{l}\text { Sportfunctionarissen } \\
\text { Sporten in de wijk met } \\
\text { voetbalclub } \\
\text { Free running }\end{array}$ & $\begin{array}{l}\text { Beweeg- en voedingsac- } \\
\text { tiviteiten }\end{array}$ & $\begin{array}{l}\text { Samen wandelen en } \\
\text { hardlopen: beweegpro- } \\
\text { gramma in gemeente. } \\
\text { 'Probeer de sport die je } \\
\text { leuk vindt' }\end{array}$ \\
\hline Private partners & $\begin{array}{l}\text { Fruit- en watercam- } \\
\text { pagne } \\
\text { Verstrekken gratis fruit, } \\
\text { sponsoringactiviteiten, } \\
\text { speurtocht }\end{array}$ & $\begin{array}{l}\text { Sponsoring bewegen en } \\
\text { voedingsactiviteiten }\end{array}$ & $\begin{array}{l}\text { Activiteit gezonde voe- } \\
\text { ding (soep maken); } \\
\text { sponsoring van bewegen } \\
\text { en voeding (bijvoorbeeld } \\
\text { financiering schoolplein) }\end{array}$ & $\begin{array}{l}\text { Supermarktrondleiding } \\
\text { Bewegen geïnitieerd } \\
\text { door voetbalclub (onder- } \\
\text { deel schoolprogramma) }\end{array}$ & $\begin{array}{l}\text { Supermarktrondleiding } \\
\text { Bewegen geïnitieerd } \\
\text { door voetbalclub (onder- } \\
\text { deel schoolprogramma) }\end{array}$ \\
\hline
\end{tabular}

\section{Factoren van invloed op de implementatie: aanpassing MIDI}

Op basis van eerder kwalitatief onderzoek in de vijf participerende gemeenten is de standaard-MIDI op enkele onderdelen aangescherpt. In totaal zijn dertien nieuwe items toegevoegd; acht daarvan zaten ook al in een voorloper van de huidige MIDI [8] en vijf items werden nieuw toegevoegd. Alle items zijn geformuleerd volgens de handleiding van MIDI [9] en zijn gescoord op een vijfpuntslikertschaal, variërend van 'volledig oneens' tot 'volledig mee eens'. Een tweede aanpassing betrof het samenvoegen van twee oorspronkelijk gescheiden items, te weten 'tevredenheid van de doelgroep' en 'samenwerking met de doelgroep' (in dit geval ouders en kinderen), in één enkel item 'tevredenheid en samenwerking'. Een derde aanpassing omvatte een zodanige herformulering van de MIDI-vraagstellingen over 'wet- en regelgeving' en 'evaluatie en feedback' dat ze beter aansloten op de context van de onderzochte integrale aanpak en belevingswereld van de professionals. Daarnaast zijn enkele van de originele dichotome (ja/nee) MIDIitems omgezet naar een vijfpuntslikerttype, te weten 'formele bekrachtiging door management', 'coördinator' en 'turbulentie'. Zo resteren in totaal 50 items, waarvan tab. 1 een overzicht biedt.

\section{Deelnemende gemeenten}

De gemeenten zijn geïncludeerd op basis van hun bereidheid tot deelname aan het onderzoek, en de beoogde diversiteit tussen de gemeenten wat betreft enkele demografische achtergrondkenmerken (tab. 1). De grootte van de gemeente varieerde van 103 ha tot 6.958 ha en het aantal inwoners van 7.345 tot 41.005 . Drie van de vijf gemeenten hebben de JOGG-aanpak geïmplementeerd, terwijl de overige twee een andere op EPODE-gebaseerde integrale aanpak hebben geïmplementeerd. De aanpakken richtten zich op het bevorderen van gezonde voeding en/of het stimuleren van voldoende beweging. De ontwikkeling van de aanpak (top-down versus bottom-up), het aantal en de soort geïmplementeerde activiteiten en het aantal 
deelnemende private organisaties verschilde per gemeente. Gemeente A implementeerde bijvoorbeeld een relatief conventionele top-downcampagne, die zich uitsluitend richtte op voeding, en waarbij vijf private partners actief waren. In gemeente $\mathrm{E}$ werd daarentegen een bottom-upstrategie gevolgd, waarbij slechts twee private organisaties betrokken waren en lag de focus op zowel voeding als bewegen. In elke gemeente is een selectie van uitvoerende professionals uitgenodigd voor deelname aan het onderzoek. Per gemeente werd een lijst opgesteld van alle professionals die volgens plan geacht werden in het kader van de aanpak activiteiten te implementeren, en die beroepshalve direct contact hadden met de einddoelgroep (jongeren en/of ouders). Gezien de omvangrijkheid van deze lijst werd een bijkomend selectiecriterium ingevoerd, namelijk of deze professionals belast waren met uitvoeringsactiviteiten die door de projectmanager/regisseur als meest kritisch werden beschouwd voor de effectiviteit van de aanpak in hun gemeente. De vragenlijsten werden op papier ingevuld 1) nadat eerst een semigestructureerd interview was afgenomen, of 2) nadat de uitvoering van bepaalde preventieactiviteiten in de praktijk was geobserveerd. Als alternatief werd de professional ook de mogelijkheid geboden de vragenlijst online in te vullen via Qualtrics (versie 2013, Qualtrics, Provo, UT).

\section{Analyse}

De gemeten MIDI-items zijn voor analyse teruggebracht tot de zeventien meest relevant geachte constructen, die elke een specifieke factor vertegenwoordigden (zie nummering bijlage 1). Doel van deze clustering was datareductie. De clustering kwam voort uit consensusvorming tussen vier onderzoekers met een achtergrond in de gezondheidsbevordering en/of het implementatieonderzoek, op basis van de criteria 'expert' - en 'face validity'. Gegevens zijn ingevoerd in IBM SPSS Statistics for Windows. Uiteindelijk werden er zes samengestelde factoren en elf één-itemfactoren gevormd (bijlage 1). De zes samengestelde factoren bleken elk voldoende intern consistent (Cronbachs alfa $\geq 0,60$ ) [14], en werden derhalve in gemiddelde somscores omgezet (per factor werden itemscores gesommeerd en gedeeld door het aantal items). De uiteindelijke score per factor varieerde van 1 'Volledig oneens met de items van dit construct' tot 5 'Volledig eens met deze items' (zie tab. 3).

Vanwege het grote personeelsverloop kwamen van slechts acht uitvoerend professionals gegevens op beide meetmomenten beschikbaar, dat wil zeggen bij aanvang en twaalf maanden later. Daardoor moest het oorspronkelijk beoogde longitudinale onderzoeksontwerp worden verlaten, en bleven twee over de tijd gespreide cross-sectionele metingen over. Voor de analyses zijn daarom alle metingen van unieke participanten van het eerste en tweede meetmoment samengevoegd, en aangevuld met uitsluitend de nameting van de acht participanten van wie ook een voormeting beschikbaar was. Om te controleren voor een mogelijke vertekening die zou kunnen ontstaan als gevolg van het verschil in ervaring met de implementatie zijn de participanten in twee groepen ingedeeld: a) nul tot twaalf maanden ervaring met de aanpak en b) meer dan twaalf maanden ervaring, en is deze dichotomie als covariaat in de analyses betrokken. Zo is er ook voor gekozen 'het aantal voorgeschreven activiteiten' als covariaat in de analyses mee te nemen. Dit vanuit de veronderstelling dat de kans op het niet uitvoeren van een activiteit groter is onder professionals die met relatief veel activiteiten zijn belast, dan onder professionals die met relatief weinig uitvoeringstaken zijn belast. Bij de eerste descriptieve analyse bleek dat 4,4\% van de antwoorden in de data ontbraken. Deze ontbrekende antwoorden bleken willekeurig verdeeld over de zeventien factoren en de twee items 'ervaring met implementatie' en 'aantal voorgeschreven activiteiten' $\left(\chi^{2}(412, n=\right.$ $115)=430,95, p=0,250)$. Er waren geen ontbrekende waarden op de uitkomstvariabele compleetheid van implementatie. Ontbrekende waarden op de factoren zijn geïmputeerd volgens de Markov Chain Monte Carlo (MCMC) methode. Zo werden de ontbrekende waarden geschat op basis van de gegevens die wel beschikbaar waren en werden de onzekerheidsmarges van die schattingen eveneens verdisconteerd. In overeenstemming met Graham, Olchowski en Gilreath [15] werd gekozen voor twintig imputaties met tien iteraties elk. Alle imputatiedatasets zijn samengevoegd zoals voorgesteld door Rubin [16], en in de resultatensectie worden de gepoolde resultaten weergegeven. Twee univariate ANOVA's zijn uitgevoerd om na te gaan of de compleetheid van implementatie significant verschilde tussen de gemeenten en tussen de betrokken sectoren. Daaruit bleek dat compleetheid onder de professionals in de onderwijssector significant lager lag dan onder de professionals in de zorg-, welzijns-, sport- en private sector $(p \leq 0,05)$. Ook bleek dat compleetheid onder professionals uit de gemeenten A en B significant lager was dan in de andere gemeenten $(p \leq 0,05)$. Om die reden is voor de variabele sector ('nee/ja-onderwijssector') en de variabele 'gemeente' (gemeente A, versus B, versus andere) gecontroleerd in de lineaire regressieanalyses. Omwille van datareductie en praktische relevantie zijn alleen die factoren in de multivariate regressieanalyses meegenomen die univariaat significant samenhingen met compleetheid. Immers, een factor die niet direct samenhangt met compleetheid kan voor verbetering van die implementatiepraktijk niet of nauwelijks als een relevant aangrijpingspunt gelden. En mocht er multivariaat wel samenhang ontstaan, dan wordt betekenisgeving vaak een complexe en tamelijk speculatieve exercitie. Hoe duidt men een factor die zelf niet samenhangt met compleetheid, maar dat uitsluitend doet bij de aanwezigheid 


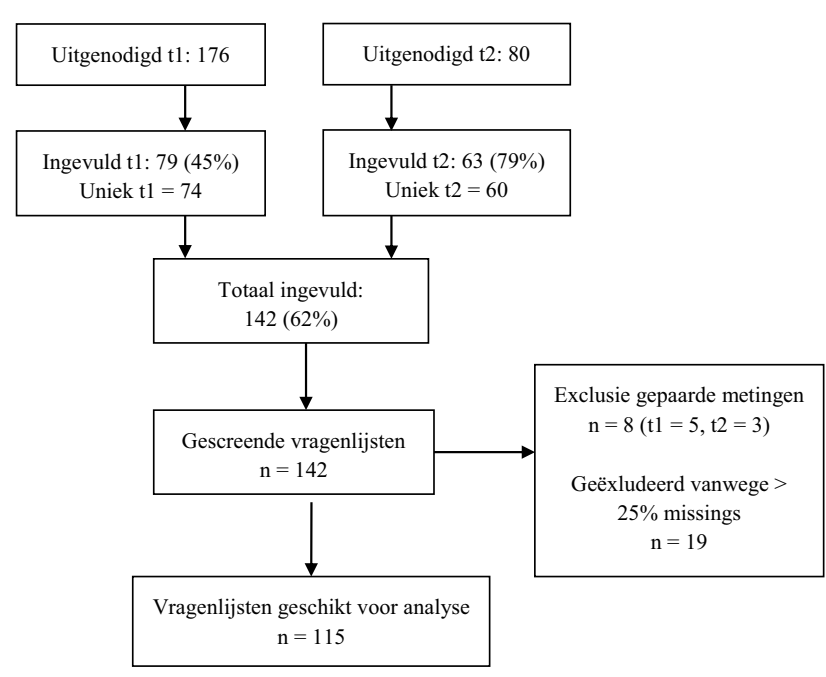

Figuur 1 Het procesvan inclusie

van andere factoren? De multivariate regressies zijn stapsgewijs uitgevoerd, indachtig de geneste structuur waarlangs de hier onderzochte innovatieprocessen verlopen. Daarom werden bij de eerste stap de factoren ingevoerd die als meest proximaal gelden voor het beoogde preventieve effect van de implementatie (i.c. de kenmerken van de gebruiker). Bij de tweede stap volgden de meer distale factoren (de kenmerken van de organisatie, de context en blootstelling aan bepaalde innovatiestrategieën). Theoretisch wordt namelijk verwacht dat voor zover distale factoren met compleetheid samenhangen, de impact daarvan niet direct maar indirect via de proximale factoren loopt. In de laatste stap werden de achtergrondkenmerken toegevoegd (zoals ervaring met de aanpak, sector en gemeente waar men werkzaam is).

\section{Resultaten}

\section{Kenmerken van de participanten}

Van de 256 uitgenodigde professionals vulden 134 de vragenlijst in: $45 \%$ van 176 die waren uitgenodigd voor de eerste meting en $79 \%$ van de 80 die waren uitgenodigd voor de tweede meting. Negentien vragenlijsten bevatten meer dan $25 \%$ ontbrekende waarden en werden om die reden geëxcludeerd. Uiteindelijk bleven 115 vragenlijsten over voor de beoogde analyses (fig. 1). Van deze 115 professionals waren er 90 (78\%) vrouw en 61 (53\%) kwamen uit gemeente A, $25 \%$ uit gemeente B, $9 \%$ uit gemeente C, $9 \%$ uit gemeente $\mathrm{D}$ en $4 \%$ uit gemeente $\mathrm{E}$. De gemiddelde leeftijd was 38 jaar (sd 11,9). Iets meer dan de helft, $57 \%$ (65), had minder dan een jaar ervaring met het implementeren van de voorgeschreven preventieactiviteiten en $43 \%$ had er meer dan een jaar ervaring mee (tab. 2). De meeste professionals waren werkzaam in de onderwijssector $(62 \%)$, gevolgd door de welzijnssector $(21 \%)$, de zorgsector ( $10 \%)$ en de overige drie sectoren (6\%). Het verschil in het aantal participanten per gemeente en sector weerspiegelt de omvang en het karakter van de verschillende aanpakken. Zo waren de aanpakken in de gemeenten D en E kleiner van opzet, en waren er daardoor minder professionals die voldeden aan de inclusiecriteria. De verschillen tussen sectoren zijn toe te schrijven aan de mate waarin de sectoren werden belast met activiteiten; doorgaans waren de onderwijs- en welzijnssector het meest belast.

\section{Compleetheid}

\section{Uitkomstvariabelen en factoren}

Het gemiddelde aantal voorgeschreven activiteiten bedroeg 19,6: in gemeente $C$ waren dat gemiddeld 4 activiteiten, in gemeente A en D gemiddeld 16, en in gemeente B en D 31. De compleetheid van implementatie bedroeg gemiddeld $52 \%$ ( $s d=29,4$ ). Compleetheid bleek het laagst onder professionals uit de onderwijssector $(M=41,5$, sd $=23)$ en was het hoogst onder professionals uit de private sector $(\mathrm{M}=$ $82,7, \mathrm{sd}=19,3$ ). Op gemeenteniveau was de compleetheid het hoogst in gemeente $\mathrm{C}$ en $\mathrm{E}$ (respectievelijk $\mathrm{M}=89,6$, sd $=17,8$ en $\mathrm{M}=89,7$, sd = 7,5), terwijl professionals uit gemeente A de laagste compleetheid rapporteerden $(M=39,5, \mathrm{sd}=25,3)$. Wat betreft factoren scoorden de participanten het hoogst op de constructen 'eigen-effectiviteitsverwachting' $(M=3,9$, $\mathrm{sd}=0,6)$ en 'belangrijkheid en taakoriëntatie' $(\mathrm{M}=$ $3,8, \mathrm{sd}=0,7)$. Participanten scoorden het laagste op gepercipieerde onveiligheid van de omgeving waarin kinderen moeten buitenspelen ('veiligheid omgeving') $(M=2,9$, sd $=1,0)$ en de mate waarin het eigen management de aanpak formeel heeft bekrachtigd ('formele bekrachtiging') $(\mathrm{M}=3,0$, sd =0,9) (tab. 3).

\section{Univariate analyses}

Univariate analyses toonden aan dat de compleetheid van implementatie positief samenhing met twaalf van de zeventien factoren, en met de hoeveelheid ervaring met de implementatie van de aanpak. Een significant lagere compleetheid van implementatie werd gevonden onder de professionals uit gemeente A en professionals die werkzaam waren in de sector 'onderwijs'. Ook bleek het aantal activiteiten waarmee een professional was belast een significant negatief effect te hebben op de implementatiegraad (tab. 3).

\section{Multivariate analyse}

De factoren die univariaat bleken samen te hangen met de compleetheid van de implementatie werden betrokken in een hiërarchische multipele regressieanalyse (tab. 3). Het complete regressiemodel bleek statistisch significant $(\mathrm{F}(12,32)=10,98, p \leq 0,001)$ en verklaarde $65 \%$ van de variantie in compleetheid (adjusted $\mathrm{R}^{2}=0,65$ ). De ervaring die men had met de implementatie van de aanpak $(\beta=0,54 ; p \leq$ 0,001; $95 \%$-BI 0,38-0,69), de eigen-effectiviteitsverwachting ( $\beta=0,32 ; p \leq 0,001$; $95 \%$-BI $0,08-0,55)$ en 
Tabel 2 Kenmerken van de steekproef

\begin{tabular}{|c|c|c|c|}
\hline Kenmerken & $\begin{array}{l}\text { Gemiddelde } \\
\text { (sd) }\end{array}$ & $\begin{array}{l}\text { Aantal } \\
(\%)\end{array}$ & $\begin{array}{l}\text { Compleetheid } \\
\text { implementatie } \\
\text { (gemiddelde } \\
\text { (sd)) }\end{array}$ \\
\hline \multicolumn{4}{|l|}{ Geslacht } \\
\hline Man & & $25(22)$ & $46,8(29,4)$ \\
\hline Vrouw & & $90(78)$ & $69,3(22,4)$ \\
\hline Leeftijd: in jaren & $38,1(11,9)$ & & \\
\hline $\begin{array}{l}\text { Werkervaring: in maan- } \\
\text { den }\end{array}$ & $133,4(111,6)$ & & \\
\hline \multicolumn{4}{|l|}{ Sector werkzaam } \\
\hline Onderwijs & & $72(62)$ & $41,5(23,0)$ \\
\hline Gezondheidszorg & & $12(10)$ & $77,8(23,2)$ \\
\hline Welzijn en sport & & $24(21)$ & $60,2(34,9)$ \\
\hline Private organisatie & & $7(6)$ & $82,7(19,3)$ \\
\hline \multicolumn{4}{|l|}{ Gemeente } \\
\hline$A$ & & $61(53)$ & $39,5(25,3)$ \\
\hline$B$ & & $29(25)$ & $52,7(27,9)$ \\
\hline c & & $10(9)$ & $89,6(17,8)$ \\
\hline D & & $10(9)$ & $66,3(16,9)$ \\
\hline$E$ & & $5(4)$ & $89,7(7,5)$ \\
\hline \multicolumn{4}{|c|}{ Ervaring met de implementatie van de activiteiten } \\
\hline 0-12 maanden & & $65(57)$ & $38,7(26,9)$ \\
\hline > 12 maanden & & $50(43)$ & $68,7(23,5)$ \\
\hline
\end{tabular}

het werkzaam zijn in gemeente $\mathrm{B}(\beta=0,24 ; p \leq 0,05$; $95 \%$-BI 0,02-0,46) bleken positief samen te hangen met de compleetheid van implementatie. Het aantal uitvoeringsactiviteiten waarmee de professional was belast $(\beta=-0,52 ; p \leq 0,05 ; 95 \%-\mathrm{BI}-0,75-0,28)$ en het formeel bekrachtigen van de implementatie van de voorgeschreven activiteiten door het management ( $\beta=-0,18 ; \quad p \leq 0,05 ; 95 \%-\mathrm{BI}-0,33-0,05)$ hingen negatief samen met compleetheid.

\section{Beschouwing}

Steeds meer gemeenten implementeren een integrale aanpak om het overgewicht onder kinderen in hun gemeente terug te dringen [16]. Om het potentiële effect van een dergelijke complexe aanpak te maximaliseren is kennis over het implementatieproces van groot belang [17]. Dit onderzoek focust als een van de eerste op een kwantitatieve toetsing van factoren die van invloed zijn op de implementatie van een dergelijke integrale aanpak.

De compleetheid van implementatie varieerde tussen sectoren en gemeenten, en bedroeg gemiddeld $52 \%$. Professionals uit de onderwijssector rapporteerden de laagste mate van compleetheid. Multivariate analyse liet zien dat de mate van compleetheid van de implementatie positief samenhing met eigen-effectiviteitsverwachtingen van de professionals, de ervaring (in tijd) opgedaan met het implementeren van de aanpak en betrokkenheid bij de aanpak in gemeente $B$. Verder bleek implementatie negatief samen te hangen met de aanwezigheid van een formele bekrachtiging door het management (zoals opname in een beleidsplan) en een relatief groot aantal voorgeschreven activiteiten.

Het van de MIDI afgeleide model [8, 9] bleek goed te passen bij de data; het multivariate model verklaarde $65 \%$ van de variantie in compleetheid van implementatie. De gevonden implementatiegraad (52\%) is relatief hoog. Hoewel meer onderzoeken naar de implementatie van een integrale aanpak een dergelijke implementatiegraad rapporteren $[18,19]$, is een compleetheid van meer dan $50 \%$ ongebruikelijk hoog te noemen [20]. Daarnaast werd een positief verband gevonden tussen de mate van ervaring met implementatie en de compleetheid van implementatie. Dit sluit aan bij Rogers Diffusion of Innovation Theory [21], die stelt dat de professionals die de implementatie van een vernieuwing op langere termijn volhouden, dit ook vaak het meest getrouw doen. Hier hoort wel de kanttekening bij dat veel professionals de implementatie van een complexe interventie niet lang continueren, zoals ook uit ons onderzoek naar voren komt. Het is dus van belang om professionals langdurig betrokken te houden en te binden aan de aanpak. Het creëren van co-benefits kan hierbij ondersteunend zijn [22]; hierbij tracht men de te implementeren aanpak te laten aansluiten bij de doelstellingen waarop het primaire proces van de professional zich al richt. Zo kan het bijvoorbeeld nuttig zijn om voor scholen inzichtelijk te maken dat de leerprestaties van kinderen verbeteren door gezonde voeding en voldoende beweging [23]. Onze bevinding dat eigeneffectiviteitsverwachtingen in sterke mate het implementatiegedrag van professionals bepalen is nog weinig in onderzoeken naar de implementatie van een integrale aanpak benoemd [10, 17, 24]. Ze zijn echter wel al vaak een invloedrijke factor gebleken in onderzoek naar de implementatie van enkelvoudige (nietintegrale) vernieuwingspogingen, binnen en buiten de publieke gezondheidszorg. Om de eigen-effectiviteit van professionals te vergroten, zou men bijvoorbeeld een aantal coachingsbijeenkomsten met wijkpartners kunnen organiseren. Ook betrokkenheid bij de opzet en het ontwerp van de aanpak kan mogelijk de eigeneffectiviteit van professionals vergroten.

\section{Relativering}

De selectie van participanten vond plaats door middel van purposeful sampling. Deze vorm van selectie bij het evalueren van complexe interventies kan mogelijk aanleiding geven tot selectiebias. Zo is ervoor gekozen die professionals te includeren die naar de mening van de projectregisseur activiteiten uitvoerden die het belangrijkst werden geacht voor het behalen van het doel van de aanpak. Dit kan ertoe hebben geleid dat vooral gemotiveerde professionals zijn geïncludeerd. Mocht dat in dit onderzoek het geval geweest zijn, dan zal dit hoofdzakelijk hebben geleid 
Tabel 3 Univariate en multivariate samenhang van factoren met compleetheid

\begin{tabular}{|c|c|c|c|c|c|c|c|c|c|c|}
\hline \multirow{3}{*}{ Factoren } & \multirow[t]{3}{*}{$\alpha$} & \multirow[t]{3}{*}{$\bar{x}(s d)$} & \multicolumn{2}{|c|}{ Univariate } & \multicolumn{6}{|c|}{ Multivariate } \\
\hline & & & \multirow[b]{2}{*}{$\beta$} & \multirow[b]{2}{*}{$95 \%-B I$} & \multicolumn{2}{|c|}{ Block 1} & \multicolumn{2}{|l|}{ Block 2} & \multicolumn{2}{|l|}{ Block 3} \\
\hline & & & & & $\beta$ & $95 \%-B I$ & $\beta$ & $95 \%-B I$ & $\beta$ & $95 \%-B I$ \\
\hline $\begin{array}{l}\text { 1. Kenmerken } \\
\text { aanpak }\end{array}$ & 0,85 & $\begin{array}{l}3,64 \\
(0,53)\end{array}$ & 0,45 & $0,28-0,62$ & & & $-0,16$ & $-0,44-0,13$ & $-0,16$ & $-0,38-0,06$ \\
\hline 2. Sociale invloed & 0,61 & $\begin{array}{l}3,38 \\
(0,65)\end{array}$ & 0,49 & $0,33-0,65$ & 0,01 & $-0,28-0,63$ & 0,02 & $-0,20-0,24$ & 0,02 & $-0,16-0,19$ \\
\hline $\begin{array}{l}\text { 3. Kennis en vaar- } \\
\text { digheden }\end{array}$ & 0,86 & $\begin{array}{l}3,69 \\
(0,72)\end{array}$ & 0,45 & $0,29-0,62$ & 0,01 & $-0,57-0,47$ & $-0,03$ & $-0,29-0,23$ & $-0,02$ & $-0,23-0,19$ \\
\hline $\begin{array}{l}\text { 4. Belangrijkheid } \\
\text { en taakoriëntatie }\end{array}$ & 0,80 & $\begin{array}{l}3,79 \\
(0,73)\end{array}$ & 0,58 & $0,43-0,73$ & 0,28 & $0,04-0,52$ & 0,22 & $-0,04-0,47$ & 0,03 & $-0,18-0,23$ \\
\hline $\begin{array}{l}\text { 5. Persoonlijk } \\
\text { voordeel }\end{array}$ & & $\begin{array}{l}3,64 \\
(0,94)\end{array}$ & 0,44 & $0,28-0,61$ & 0,03 & $-0,177-0,237$ & 0,07 & $-0,14-0,29$ & 0,13 & $-0,04-0,31$ \\
\hline $\begin{array}{l}\text { 6. Uitkomstver- } \\
\text { wachtingen }\end{array}$ & & $\begin{array}{l}3,39 \\
(0,96)\end{array}$ & 0,43 & $0,26-0,59$ & 0,17 & $-0,013-0,354$ & 0,14 & $-0,05-0,33$ & 0,03 & $-0,18-0,12$ \\
\hline $\begin{array}{l}\text { 7. Eigen-effectivi- } \\
\text { teitsverwachting }\end{array}$ & & $\begin{array}{l}3,90 \\
(0,64)\end{array}$ & 0,58 & $0,43-0,73$ & 0,25 & $0,11-1,32$ & 0,30 & $0,00-0,59$ & 0,32 & $0,08-0,55$ \\
\hline $\begin{array}{l}\text { 8. Voorwaarden } \\
\text { implementatie }\end{array}$ & 0,83 & $\begin{array}{l}3,30 \\
(0,75)\end{array}$ & 0,39 & $0,23-0,56$ & & & $-0,07$ & $-0,29-0,15$ & 0,02 & $-0,15-0,18$ \\
\hline $\begin{array}{l}\text { 9. Turbulentie in } \\
\text { organisatie }\end{array}$ & & $\begin{array}{l}3,12 \\
(1,06)\end{array}$ & 0,11 & $-0,08-0,30$ & & & & & & \\
\hline $\begin{array}{l}\text { 10. Formele be- } \\
\text { krachtiging }\end{array}$ & & $\begin{array}{l}3,03 \\
(0,91)\end{array}$ & 0,25 & $0,07-0,44$ & & & $-0,18$ & $-0,37-0,01$ & $-0,18$ & $-0,33--0,02$ \\
\hline $\begin{array}{l}\text { 11. Samenwerking } \\
\text { organisatie }\end{array}$ & & $\begin{array}{l}3,61 \\
(0,90)\end{array}$ & 0,47 & $0,30-0,63$ & & & 0,10 & $-0,10-0,31$ & 0,02 & $-0,15-0,19$ \\
\hline $\begin{array}{l}\text { 12. Invoerstrate- } \\
\text { gieën }\end{array}$ & 0,85 & $\begin{array}{l}3,13 \\
(0,79)\end{array}$ & 0,54 & $0,39-0,70$ & & & 0,28 & $0,00-0,56$ & 0,14 & $-0,07-0,35$ \\
\hline $\begin{array}{l}\text { 13. Steun ge- } \\
\text { meente }\end{array}$ & & $\begin{array}{l}3,19 \\
(0,76)\end{array}$ & 0,05 & $-0,15-0,25$ & & & & & & \\
\hline $\begin{array}{l}\text { 14. Samenwerking } \\
\text { partners }\end{array}$ & & $\begin{array}{l}3,11 \\
(0,77)\end{array}$ & 0,26 & $0,07-0,45$ & & & 0,07 & $-0,14-0,28$ & 0,01 & $-0,15-0,18$ \\
\hline $\begin{array}{l}\text { 15. Fysieke omge- } \\
\text { ving }\end{array}$ & & $\begin{array}{l}3,29 \\
(1,08)\end{array}$ & $-0,16$ & $-0,36-0,04$ & & & & & & \\
\hline $\begin{array}{l}\text { 16. Veiligheid } \\
\text { omgeving }\end{array}$ & & $\begin{array}{l}2,85 \\
(1,02)\end{array}$ & 0,03 & $-0,18-0,24$ & & & & & & \\
\hline 17. Rol etniciteit & & $\begin{array}{l}3,11 \\
(0,94)\end{array}$ & 0,06 & $-0,13-0,25$ & & & & & & \\
\hline Gemeente $A^{a}$ & & & $-0,44$ & $-0,61--0,28$ & & & & & $-0,14$ & $-0,33-0,05$ \\
\hline Gemeente $\mathrm{B}^{\mathrm{a}}$ & & & 0,02 & $-0,17-0,20$ & & & & & 0,24 & $0,02-0,46$ \\
\hline Onderwijssector & & & $-0,45$ & $-0,61--0,29$ & & & & & 0,02 & $-0,17,0,21$ \\
\hline $\begin{array}{l}\text { Ervaring implemen- } \\
\text { tatie (tijd) }\end{array}$ & & & 0,50 & $0,35-0,67$ & & & & & 0,54 & $0,38-0,69$ \\
\hline $\begin{array}{l}\text { Aantal voorgeschre- } \\
\text { ven activiteiten }\end{array}$ & & & $-0,23$ & $-0,41--0,05$ & & & & & $-0,52$ & $-0,75--0,28$ \\
\hline Adjusted $\mathrm{R}^{2}$ & & & & & 0,34 & & 0,38 & & 0,65 & \\
\hline$F$ for change in $R^{2}$ & & & & & 10,08 & & 6,45 & & 12,32 & \\
\hline
\end{tabular}

tot een overschatting van rechte tellingen, zoals de gemiddelde scores op factoren en compleetheid van gebruik. Voor zover de rechte tellingen hierdoor mogelijk zijn vertekend, zal die vertekening geen gevolgen hebben gehad voor de gerapporteerde verbanden zolang die vertekening voor alle variabelen systematisch hetzelfde was. De aangepaste versie van MIDI zoals gebruikt in dit onderzoek kent ook enkele beperkingen. Sommige constructen zijn slechts met één item gemeten, wat kan leiden tot instabiliteit en een verminderde (predictieve) validiteit [25]. Ook is de graad van implementatie vastgesteld door middel van zelfrapportage. Hoewel we hebben getracht de vertekening door sociale wenselijkheid [26] te vermijden door respondenten te wijzen op het vertrouwelijk karakter van de dataverzameling en rapportage, is niet volledig uit te sluiten dat deze de beantwoording van de vragen heeft beïnvloed. 


\section{Conclusie}

De resultaten van dit onderzoek wijzen erop dat de belangrijkste aangrijpingspunten voor verbetering van de implementatie van de onderzochte integrale aanpakken van overgewicht bij kinderen gezocht moeten worden in het vergroten van de eigen-effectiviteitsverwachting, het bieden van voldoende tijd/gelegenheid om ervaring op te doen met de implementatie en een niet al te ambitieus samengesteld pakket van invoeringsactiviteiten. Aanbevelingen voor toekomstig onderzoek richten zich op het verdergaand valideren en verfijnen van de MIDI voor het monitoren van het proces van implementatie van deze en andere complex samengestelde innovaties. Daarnaast zou nagegaan moeten worden op welke wijze MIDI zinvol geïntegreerd kan worden in de Behavior Change Ball (BCB) [27]. Deze bal beschrijft de kwaliteiten die nodig zijn om een integraal gezondheidsbeleid te realiseren en kan als houvast bij de vormgeving van integraal gezondheidsbeleid gebruikt worden door beleidsmakers op strategisch, tactisch en operationeel niveau. De MIDI biedt beleidsmakers sturingsinformatie voor factoren waarop aangegrepen kan/moet worden om het implementatieproces op het niveau van de professional te verbeteren. Een integratie van MIDI en BCB zou hen kunnen ondersteunen bij het maken van een koppeling tussen veranderingsprocessen op beleidsen praktijkniveau, en hun wederzijdse beïnvloedingsmechanismen.

\section{Advies voor onderzoek en praktijk}

- Er is grote behoefte aan een vragenlijst die inzicht geeft in de factoren die van invloed zijn op het implementatieproces van de complexe interventies, zoals de integrale aanpak. De aangepaste versie van de MIDI zou hiervoor gebruikt kunnen worden, maar moet verder worden aangepast en verfijnd.

- Implementatie van de integrale aanpak kan mogelijk worden verbeterd door de eigen effectiviteit van professionals te verhogen, bijvoorbeeld door het organiseren van stakeholder-meetings en de inzet van coaches, en door de professionals te betrekken bij de ontwikkeling en aansturing van de aanpak.

- Er moet voldoende tijd worden uitgetrokken voor implementatie van de aanpak. De onderzoeksresultaten laten immers zien dat professionals die langer implementeren ook beter implementeren. Het creëren van co-benefits, bijvoorbeeld door activiteiten te laten aansluiten bij de doelstellingen vanuit het primaire proces van de professional, zou langdurigere implementatie van de integrale aanpak wellicht kunnen bevorderen.

Financiering Dit onderzoek is gefinancierd door ZonMW (projectnummer 200100001). 


\section{Bijlage}

Bijlage: factoren en items van de aangepaste MIDI

\begin{tabular}{|c|c|c|c|c|c|}
\hline \multirow[t]{2}{*}{ Kenmerk } & \multicolumn{4}{|l|}{ Factoren } & \multirow[t]{2}{*}{ Items } \\
\hline & & MIDI & Fleur & Kwal & \\
\hline \multirow[t]{14}{*}{ Aanpak } & \multicolumn{5}{|l|}{ 1. Kenmerken aanpak } \\
\hline & (a) Compleetheid & - & & & $\begin{array}{l}\text { De aanpak biedt mij alle informatie en materialen die nodig zijn om goed } \\
\text { met het programma te werken }\end{array}$ \\
\hline & (b) Procedurele helderheid & - & & & $\begin{array}{l}\text { Het is voor mij duidelijk welke activiteiten ik moet uitvoeren voor de aan- } \\
\text { pak }\end{array}$ \\
\hline & (c) Aantrekkelijkheid & & ○ & & Ik vind de activiteiten en materialen van de aanpak aantrekkelijk \\
\hline & (d) Kwaliteit materialen & & & - & De materialen van de aanpak zijn duurzaam en gaan lang mee \\
\hline & (e) Juistheid & $\bullet$ & & & Naar mijn idee is de aanpak gebaseerd op feitelijk juiste kennis \\
\hline & (f) Complexiteit & • & & & De aanpak is voor mij te ingewikkeld en complex om mee te werken \\
\hline & (g) Organisatie & & & - & Ik vind de aanpak goed opgezet en georganiseerd \\
\hline & $\begin{array}{l}\text { (h) Congruentie huidige werk- } \\
\text { wijze }\end{array}$ & - & & & De aanpak sluit goed aan bij hoe ik gewend ben te werken \\
\hline & (i) Aanpasbaarheid & & & - & Waar nodig kan ik de aanpak aanpassen aan mijn werkwijze \\
\hline & $\begin{array}{l}\text { (j) Compatibiliteit met andere } \\
\text { interventies }\end{array}$ & & & ○ & $\begin{array}{l}\text { De aanpak sluit goed aan op andere interventies rond overgewichtpreven- } \\
\text { tie in deze gemeente }\end{array}$ \\
\hline & (k) Relatief voordeel & & ○ & & $\begin{array}{l}\text { Het uitvoeren van de aanpak levert een meerwaarde op voor de kinderen } \\
\text { van deze gemeente }\end{array}$ \\
\hline & (I) Relevantie doelgroep & $\bullet$ & & & Ik vind dat de aanpak goed aansluit op de kinderen met wie ik werk \\
\hline & (m) Zichtbaarheid uitkomsten & - & & & $\begin{array}{l}\text { Ik vind dat de effecten van de aanpak duidelijk zichtbaar zijn bij de kinde- } \\
\text { ren met wie ik werk }\end{array}$ \\
\hline \multirow[t]{19}{*}{ Gebruiker } & \multicolumn{5}{|l|}{ 2. Sociale invloed } \\
\hline & (a) Sociale steun & - & & & $\begin{array}{l}\text { Ik kan op voldoende hulp rekenen tijdens het uitvoeren van de aanpak } \\
\text { (collega's, leidinggevende, partners in de gemeente) }\end{array}$ \\
\hline & $\begin{array}{l}\text { (b) Tevredenheid en medewer- } \\
\text { king doelgroep }\end{array}$ & $\bullet$ & & & $\begin{array}{l}\text { Ik verwacht dat kinderen/ouders over het algemeen meedoen aan en } \\
\text { tevreden zijn over de activiteiten }\end{array}$ \\
\hline & (c) Subjectieve norm & $\bullet$ & & & $\begin{array}{l}\text { In hoeverre verwachten de volgende personen dat u de aanpak uitvoert: } \\
\text { collega's, leidinggevende, partners in de gemeente, kinderen/ouders? }\end{array}$ \\
\hline & (d) Descriptieve norm & $\bullet$ & & & $\begin{array}{l}\text { Welk deel van uw collega's die de aanpak zouden moeten uitvoeren, doet } \\
\text { dit ook in de praktijk? }\end{array}$ \\
\hline & $\begin{array}{l}\text { (e) Zichtbaarheid aanpak in } \\
\text { gemeente }\end{array}$ & & & $\bullet$ & $\begin{array}{l}\text { Welk deel van de organisaties in de gemeente die de aanpak zouden } \\
\text { moeten uitvoeren, doet dit ook in de praktijk? }\end{array}$ \\
\hline & \multicolumn{5}{|l|}{ 3. Kennis en vaardigheden } \\
\hline & (a) Kennis & $\bullet$ & & & Ik beschik over voldoende kennis om de aanpak uit te voeren \\
\hline & (b) Vaardigheden & & $\bullet$ & & Ik beschik over voldoende vaardigheden om de aanpak uit te voeren \\
\hline & (c) Bewust van inhoud & $\bullet$ & & & In hoeverre bent u op de hoogte van de werkwijze van de aanpak? \\
\hline & (d) Helderheid rol & & & - & $\begin{array}{l}\text { Het is duidelijk wat van mij als ... verwacht wordt binnen de uitvoering } \\
\text { van de aanpak }\end{array}$ \\
\hline & \multicolumn{5}{|l|}{ 4. Belangrijkheid en taakoriëntatie } \\
\hline & (a) Professionele verplichting & \multirow[t]{3}{*}{ • } & & & Het uitvoeren van de aanpak hoort bij mijn werk als ... \\
\hline & \multirow[t]{2}{*}{ (b) Belangrijkheid } & & \multirow[t]{2}{*}{ - } & & De preventie van overgewicht bij kinderen vind ik belangrijk \\
\hline & & & & & $\begin{array}{l}\text { Ik voel mij persoonlijk betrokken bij de preventie van overgewicht bij kinde- } \\
\text { ren }\end{array}$ \\
\hline & (c) Gedeelde doelen & & $\bullet$ & & $\begin{array}{l}\text { De doelen van de aanpak sluiten goed aan bij de doelen die ik vanuit mijn } \\
\text { werk nastreef }\end{array}$ \\
\hline & 5. Persoonlijke voordeel & $\bullet$ & & & Ik ervaar persoonlijke voordelen door het uitvoeren van de aanpak \\
\hline & 6. Uitkomstverwachtingen & - & & & $\begin{array}{l}\text { Ik verwacht dat de aanpak zal bijdragen aan de preventie van overgewicht } \\
\text { bij de kinderen met wie ik werk }\end{array}$ \\
\hline & $\begin{array}{l}\text { 7. Eigen-effectiviteitsverwach- } \\
\text { ting }\end{array}$ & $\bullet$ & & & $\begin{array}{l}\text { Ik heb er vertrouwen in dat ik in staat ben om de aanpak volgens de ge- } \\
\text { stelde doelstellingen uit te voeren }\end{array}$ \\
\hline
\end{tabular}


Bijlage: (Vervolg)

\begin{tabular}{|c|c|c|c|c|c|}
\hline \multirow[t]{2}{*}{ Kenmerk } & \multicolumn{4}{|l|}{ Factoren } & \multirow[t]{2}{*}{ Items } \\
\hline & & MIDI & Fleur & Kwal & \\
\hline \multirow[t]{10}{*}{ Organisatie } & \multicolumn{5}{|l|}{ 8. Voorwaarden implementatie } \\
\hline & (a) Capaciteit/bezettingsgraad & - & & & $\begin{array}{l}\text { Er is voldoende personeel om de aanpak uit te voeren zoals gevraagd en } \\
\text { gepland }\end{array}$ \\
\hline & $\begin{array}{l}\text { (b) Beschikbaarheid informatie } \\
\text { over gebruik aanpak }\end{array}$ & ○ & & & $\begin{array}{l}\text { Ik heb in mijn organisatie gemakkelijk toegang tot informatie over hoe de } \\
\text { aanpak uitgevoerd moet worden }\end{array}$ \\
\hline & (c) Financiële middelen & ○ & & & $\begin{array}{l}\text { Er zijn voor mij voldoende financiële middelen beschikbaar om de aanpak } \\
\text { uit te voeren zoals gevraagd }\end{array}$ \\
\hline & $\begin{array}{l}\text { (d) Beschikbaarheid materialen } \\
\text { en voorzieningen }\end{array}$ & ○ & & & $\begin{array}{l}\text { Mijn organisatie stelt mij voldoende materialen en voorzieningen beschik- } \\
\text { baar om de aanpak uit te voeren zoals gevraagd }\end{array}$ \\
\hline & (e) Tijd & ○ & & & Ik heb voldoende tijd om de aanpak uit te voeren zoals gevraagd \\
\hline & $\begin{array}{l}\text { (f) Vervanging bij personeels- } \\
\text { verloop }\end{array}$ & ○ & & & $\begin{array}{l}\text { In mijn organisatie worden collega's die de aanpak uitvoeren en de organi- } \\
\text { satie verlaten tijdig vervangen door medewerkers; zij worden ingewerkt }\end{array}$ \\
\hline & 9. Turbulentie in organisatie & ○ & & & $\begin{array}{l}\text { Er zijn binnen mijn organisatie veranderingen gaande (fusie, verhuizing, } \\
\text { reorganisaties, grote vernieuwingen) die de uitvoer van de aanpak in de } \\
\text { weg staan }\end{array}$ \\
\hline & 10. Formele bekrachtiging & ○ & & & $\begin{array}{l}\text { Er zijn binnen mijn organisatie formeel afspraken vastgelegd over het uit- } \\
\text { voeren van de aanpak (bijvoorbeeld in beleid, werkplannen en dergelijke) }\end{array}$ \\
\hline & 11. Samenwerking organisatie & & ○ & & $\begin{array}{l}\text { In mijn organisatie bestaat goede samenwerking tussen collega's die de } \\
\text { aanpak uitvoeren }\end{array}$ \\
\hline \multirow{8}{*}{$\begin{array}{l}\text { Invoer- } \\
\text { strategieën }\end{array}$} & \multicolumn{5}{|l|}{ 12. Invoerstrategieën } \\
\hline & (a) Instructie & & & ○ & Van tevoren is mij duidelijk uitgelegd hoe ik de aanpak moet uitvoeren \\
\hline & (b) Training & & & ○ & Ik heb voldoende training gehad om de aanpak te kunnen uitvoeren \\
\hline & (c) Evaluatie en feedback & ○ & & & $\begin{array}{l}\text { Er is regelmatig overleg binnen mijn organisatie om het uitvoeren van de } \\
\text { aanpak te evalueren }\end{array}$ \\
\hline & (d) Voorbereidingstijd & & ○ & & $\begin{array}{l}\text { Ik heb voldoende voorbereidingstijd gehad om de aanpak te kunnen uitvoe- } \\
\text { ren }\end{array}$ \\
\hline & $\begin{array}{l}\text { (e) Betrokken bij ontwikkelen/ } \\
\text { aanpassen }\end{array}$ & & ? & & $\begin{array}{l}\text { Ik ben als professional voldoende betrokken geweest bij de ontwikkeling } \\
\text { van de aanpak }\end{array}$ \\
\hline & (f) Actieplan & & & - & $\begin{array}{l}\text { Ik heb een duidelijk plan gemaakt over hoe en wanneer ik met de aanpak } \\
\text { ga werken }\end{array}$ \\
\hline & (g) Coördinator & ○ & & & $\begin{array}{l}\text { Is er in uw organisatie een coördinator aanwezig voor het invoeren van de } \\
\text { aanpak? }\end{array}$ \\
\hline \multirow[t]{5}{*}{ Context } & 13. Steun gemeente & - & & & $\begin{array}{l}\text { Voor de aanpak ontvang ik voldoende steun vanuit de gemeente en haar } \\
\text { beleid }\end{array}$ \\
\hline & 14. Samenwerking partners & & & - & $\begin{array}{l}\text { De samenwerking met andere organisaties in de gemeente bij het uitvoe- } \\
\text { ren van de aanpak verloopt soepel en makkelijk }\end{array}$ \\
\hline & 15. Fysieke omgeving & & & ? & $\begin{array}{l}\text { Binnen de gemeente zijn er mogelijkheden voor kinderen om te bewegen } \\
\text { (een grasveld of speeltuin) }\end{array}$ \\
\hline & 16. Veiligheid omgeving & & & - & $\begin{array}{l}\text { Binnen de gemeente is het gevaarlijk voor kinderen om buiten te spelen of } \\
\text { naar school te fietsen/wandelen (druk verkeer, criminaliteit) }\end{array}$ \\
\hline & 17. Rol etniciteit & & & ○ & $\begin{array}{l}\text { Ik verwacht dat kinderen met overgewicht met een of twee ouders van } \\
\text { niet-westerse herkomst meer zullen profiteren van de aanpak }\end{array}$ \\
\hline
\end{tabular}

\section{Literatuur}

1. Lobstein T, Jackson-Leach R, Moodie ML, et al. Child and adolescent obesity: part of a bigger picture. Lancet. 2015;385:2510-20.

2. Biro FM, Wien M. Childhood obesity and adult morbidities. Am J Clin Nutr. 2010;91:1499S-505S.

3. Birch LL, Ventura AK. Preventing childhood obesity: what works? Int J Obes (Lond). 2009;33 (Suppl 1):S74-S81.

4. Koperen TM van, Jebb SA, Summerbell CD, et al. Characterizing the EPODE logic model: unravelling the past and informing the future. Obes Rev. 2013;14:162-70.

5. Romon M, Lommez A, Tafflet M, et al. Downward trends in the prevalence of childhood overweight in the setting of 12- year school- and community-based programmes. Public Health Nutr. 2009;12:1735-42.

6. Borys JM. CBI Evaluation: 20 years experience from Fleurbaix-Laventie to EPODE. 2013. International Network.

7. Merzel C, D'Afflitti J. Reconsidering community-based health promotion: promise, performance, and potential. Am J Public Health. 2003;93:557-74.

8. Fleuren M, Wiefferink K, Paulussen T. Determinants of innovation within health care organizations: literature review and Delphi study. Int JQual Health Care. 2004;16:107-23.

9. Fleuren MA, Paulussen TG, Dommelen Pvan, et al. Towards a measurement instrument for determinants of innovations. Int JQual Health Care. 2014;26:501-10. 
10. Proctor E, Silmere H, Raghavan R, et al. Outcomes for implementation research: conceptual distinctions, measurement challenges, and research agenda. Adm Policy Ment Health. 2011;38:65-76.

11. Richards Z, Kostadinov I, Jones M, et al. Assessing implementation fidelity and adaptation in a community-based childhood obesity prevention intervention. Health Educ Res. 2014;29(6):918. https://doi.org/10.1093/her/cyu053.

12. Kleij RM van der, Coster N, Verbiest M, et al. The implementation of intersectoral community approaches targeting childhood obesity: a systematic review. Obes Rev. 2015;16(6):454-72.

13. Carroll C, Patterson M, Wood S, et al. A conceptual framework for implementation fidelity. Implement Sci. 2007;2:40

14. Bland JM, Altman DG. Statistics notes: Cronbach's alpha. BMJ. 1997;314:572.

15. Graham JW, Olchowski AE, Gilreath TD. How many imputations are really needed? Some practical clarifications of multiple imputation theory. PrevSci. 2007;8:206-13.

16. Rubin DB. Multiple imputation for nonresponse in surveys. New Jersey: John Wiley \& Sons; 2004.

17. Greenhalgh T, Robert G, Macfarlane F, et al. Diffusion of innovationsin service organizations: systematic review and recommendations. MilbankQ. 2004;82:581-629.

18. Gittelsohn J, Dennisuk LA, Christiansen K, et al. Development and implementation of Baltimore Healthy Eating Zones: a youth-targeted intervention to improve the urban food environment. Health Educ Res. 2013;28:732-44.

19. Rosecrans AM, Gittelsohn J, Ho LS, et al. Process evaluation of a multi-institutional community-based program for diabetes prevention among first nations. Health Educ Res. 2008;23:272-86.

20. Wiltsey Stirman S, Kimberly J, Cook N, et al. The sustainability of new programs and innovations: a review of the empirical literature and recommendations for future research. Implement Sci. 2012;7:17.

21. Rogers EM. Diffusion of innovations. New York: The Free Press; 2003.

22. Jones M, Verity F. Partnerships in obesity prevention: maximising co-benefits. Health Promot J Austr. 2017;28:44-51.

23. Hollar D, Messiah SE, Lopez-Mitnik GT, et al. Effect of a twoyear obesity prevention intervention on percentile changes in body mass index and academic performance in lowincome elementary school children. Am J Public Health. 2010;100:646-53.

24. Davis SM, Sanders SG, FitzGerald C, et al. CHILE: an evidence-based preschool intervention for obesity prevention in Head Start. J Sch Health. 2013;83:223-9.

25. Diamantopoulos A, Sarstedt M, Fuchs C, et al. Guidelines for choosing between multi-item and single-item scales for construct measurement: a predictive validity perspective. JAcad Mark Sci. 2012;40:434-49.

26. Hogue A, Dauber S, Lichvar E, et al. Validity of therapist self-report ratings of fidelity to evidence-based practices for adolescent behavior problems: correspondence between therapists and observers. Adm Policy Ment Health. 2015;42:229-43.

27. Hendriks A, Jansen W, Gubbels J, et al. Proposing a conceptual framework for integrated local public health policy, applied to childhood obesity - the behavior change ball. ImplementSci. 2013;8:46. 